Communications in Physics, Vol.23, No. 1 (2013), pp. 75-83

\title{
INFLUENCE OF REACTION TEMPERATURE ON OPTICAL PROPERTY OF Mn-DOPED ZnS NANOPARTICLES
}

\author{
BUI HONG VAN AND PHAM VAN BEN \\ Hanoi University of Science, Vietnam National University, Hanoi \\ HOANG NAM NHAT \\ University of Engineering and Technology, \\ Vietnam National University, Hanoi
}

\begin{abstract}
The reaction temperature has essential effect on quality of the product synthesized by hydrothermal method. We report here the variation of the optical characteristics of $M n$ doped $\mathrm{ZnS}$ nanocrystallites prepared by mean of the stated method from $\mathrm{Zn}\left(\mathrm{CH}_{3} \mathrm{COO}_{2} .2 \mathrm{H}_{2} \mathrm{O}\right.$, $\mathrm{Mn}\left(\mathrm{CH}_{3} \mathrm{COO}\right)_{2} \cdot 4 \mathrm{H}_{2} \mathrm{O}$ and $\mathrm{Na}_{2} \mathrm{~S}_{2} \mathrm{O}_{3} .5 \mathrm{H}_{2} \mathrm{O}$ as the precursors. The reaction temperature was set to vary from $120^{\circ} \mathrm{C}$ to $240^{\circ} \mathrm{C}$ at a constant reaction time of 15 hours. The XRD patterns showed that, for the reaction temperature range from 120 to $160^{\circ} \mathrm{C}$, the obtained products possessed a cubic $T_{d}^{2}-F \overline{4} 3 m$ and a wurtzite $C_{6 v}^{4}-P 6{ }_{3} m c$ structure, in which the cubic phase was dominant. At the temperature range from 180 to $240^{\circ} \mathrm{C}$, the structures exhibited a cubic phase with the lattice constant increased from 5.41 to $5.43 \AA$. The photoluminescence spectra showed that with the increase of reaction temperature from 120 to $240^{\circ} \mathrm{C}$ the intensity of a blue band around 425 - 500 $n m$ (attributed to both $Z n$, S vacancies) gradually decreased while the intensity of a yellow-orange band at $585 \mathrm{~nm}$ (attributed to the ${ }^{4} T_{1}\left({ }^{4} G\right)-{ }^{6} A_{1}\left({ }^{6} S\right)$ transition of $\mathrm{Mn}^{2+}$ ions) was enhanced and reached maximum at $220^{\circ} \mathrm{C}$. The excitation spectra of the $585 \mathrm{~nm}$ band recorded at $160^{\circ} \mathrm{C}$ showed a band at $335 \mathrm{~nm}$ which should be assigned to the near band-edge absorption. With increasing temperature to 200-240 ${ }^{\circ} \mathrm{C}$ the new bands appeared at 390, 430, 467, $494 \mathrm{~nm}$. The intensity of these bands increased with temperature and achieved the maxima at $220^{\circ} \mathrm{C}$. They should be attributed to the absorption transitions of electrons from ground state ${ }^{6} A_{1}\left({ }^{6} S\right)$ to excited states ${ }^{4} E\left({ }^{4} D\right)$; ${ }^{4} T_{2}\left({ }^{4} D\right) ;{ }^{4} A_{1}\left({ }^{4} G\right)-{ }^{4} E\left({ }^{4} G\right) ;{ }^{4} T_{2}\left({ }^{4} G\right)$ of $M n^{2+}\left(3 d^{5}\right)$ ions, respectively. The bands at $467,494 \mathrm{~nm}$ only exposed clearly in the absorption spectra at $220^{\circ} \mathrm{C}$ and $240^{\circ} \mathrm{C}$.
\end{abstract}

\section{INTRODUCTION}

In recent years the Mn-doped $\mathrm{ZnS}$ nanomaterials have attracted a lot of attention of scientists for both fundamental and application driven interests due to the raising demands in optoelectronics, biological markers, photocatalysis etc. [1-5]. In order to synthesize this material, there are many different methods such as co-precipitation, hydrothermal, sol-gel, electrodeposition, $\gamma$-iradiation ... The applied precursor chemicals usually include $\mathrm{Zn}^{2+}$, $\mathrm{S}^{2-}, \mathrm{Mn}^{2+}$. The $\mathrm{S}^{2-}$ source can be created from organic or inorganic compounds such as $\mathrm{Na}_{2} \mathrm{~S}, \mathrm{Na}_{2} \mathrm{~S}_{2} \mathrm{O}_{3} .5 \mathrm{H}_{2} \mathrm{O}, \mathrm{CS}\left(\mathrm{NH}_{2}\right)_{2}$ thioglycolic acid $\mathrm{C}_{2} \mathrm{H}_{4} \mathrm{O}_{2} \mathrm{~S}$ (TGA). Among the listed, there was only a few reports available that were involved with $\mathrm{Na}_{2} \mathrm{~S}_{2} \mathrm{O}_{3} .5 \mathrm{H}_{2} \mathrm{O}$ as the $\mathrm{S}^{2-}$ source. K.R.Murali and S.Kumaresan [3] have prepared the deposited $\mathrm{ZnS}$ films from $\mathrm{Na}_{2} \mathrm{~S}_{2} \mathrm{O}_{3}$ by mean of the brush electrodeposition technique. Their products showed only the weak bands at 420, $480 \mathrm{~nm}$. Xuan Xue and co-workers [4] have also prepared the 
ZnS nanoballs with average diameter of 50 - $120 \mathrm{~nm}$ by mean of $\gamma$-irradiation method. But only Changlong Jiang and co-workers [6] have presented a hydrothermal synthesis of micro-sized spheres and nano-sized hollow spheres $\mathrm{ZnS}$ from $\mathrm{Na}_{2} \mathrm{~S}_{2} \mathrm{O}_{3} .5 \mathrm{H}_{2} \mathrm{O}$ (reaction temperature of $200^{\circ} \mathrm{C}$ and time of 4 hours). Therefore, we present in this paper the results of a study of the effect of reaction temperature on the optical quality of Mn-doped $\mathrm{ZnS}$ nanoparticles prepared in the range of reaction temperature from 120 to $240^{\circ} \mathrm{C}$ from $\mathrm{Na}_{2} \mathrm{~S}_{2} \mathrm{O}_{3} .5 \mathrm{H}_{2} \mathrm{O}, \mathrm{Zn}\left(\mathrm{CH}_{3} \mathrm{COO}\right)_{2} .2 \mathrm{H} 2 \mathrm{O}, \mathrm{Mn}\left(\mathrm{CH}_{3} \mathrm{COO}\right)_{2} .4 \mathrm{H}_{2} \mathrm{O}$ and at a constant reaction time of 15 hours.

\section{EXPERIMENTAL}

The Mn-doped $\mathrm{ZnS}$ nanoparticles were prepared as follows. First by dissolving $\mathrm{Zn}\left(\mathrm{CH}_{3} \mathrm{COO}\right)_{2} .2 \mathrm{H}_{2} \mathrm{O}, \mathrm{Mn}\left(\mathrm{CH}_{3} \mathrm{COO}\right)_{2} .4 \mathrm{H}_{2} \mathrm{O}$ and $\mathrm{Na}_{2} \mathrm{~S}_{2} \mathrm{O}_{3} .5 \mathrm{H}_{2} \mathrm{O}$ in the deionized water we created the solutions of $\mathrm{Zn}\left(\mathrm{CH}_{3} \mathrm{COO}\right)_{2} 0.1 \mathrm{M}(\mathrm{A}), \mathrm{Mn}\left(\mathrm{CH}_{3} \mathrm{COO}\right)_{2} 0.01 \mathrm{M}$ (B) and $\mathrm{Na}_{2} \mathrm{~S}_{2} \mathrm{O}_{3} 0.1 \mathrm{M}(\mathrm{C})$. Then by mixing solution A with solution $\mathrm{B}$ in the stoichiometric volume ratios we received $30 \mathrm{ml}$ mixture solution $\mathrm{D}$, which was then stirred for 60 minutes. After that, the solution $\mathrm{C}$ was slowly dropped into the solution $\mathrm{D}$ and stirred further for 60 minutes. We transferred the mixed solution into the teflon-lined stainless steel autoclave, which was sealed and maintained with reaction temperature in the range from 120 to $240^{\circ} \mathrm{C}$ for 15 hours. The autoclave was then left to cool down to room temperature. In the hydrothermal process discussed above, the Mn-doped $\mathrm{ZnS}$ nanoparticles were formed as followed:

$$
\begin{aligned}
4 \mathrm{Na}_{2} \mathrm{~S}_{2} \mathrm{O}_{3} & \rightarrow \mathrm{Na}_{2} \mathrm{~S}+3 \mathrm{Na}_{2} \mathrm{SO}_{4}+4 \mathrm{~S} \\
\mathrm{Zn}\left(\mathrm{CH}_{3} \mathrm{COO}\right)_{2}+\mathrm{Na}_{2} \mathrm{~S} & \rightarrow \mathrm{ZnS} \downarrow+2 \mathrm{CH}_{3} \mathrm{COONa} \\
\mathrm{Mn}\left(\mathrm{CH}_{3} \mathrm{COO}\right)_{2}+\mathrm{Na}_{2} \mathrm{~S} & \rightarrow \mathrm{MnS} \downarrow+2 \mathrm{CH}_{3} \mathrm{COONa}
\end{aligned}
$$

The resultant containing ZnS:Mn was a white solid powder suspension which was then filted, washed with double distilled water several times, and dried at $60^{\circ} \mathrm{C}$ for 10 hours in open air. The crystalline structure of samples was examined by using the X-ray diffraction technique on XD8 Advance Bruker Diffractometer equipped with the $\mathrm{Cu}-\mathrm{K}_{\alpha}$ radiation $(\lambda=1.54056 \AA)$. The surface morphology was studied by mean of Transmission Electron Microscope (JEM-1010 TEM). The photoluminescence (PL), photoluminescence excitation (PLE) and absorption spectra were obtained at $300 \mathrm{~K}$ with the excited wavelength at $325 \mathrm{~nm}$ from a He - Cd laser, a xenon lamp XFOR - 450, hydro, and halogen lamp and measured on Oriel - Spec MS - 257, FL3-22 and Jasco - V670 spectrometers, respectively.

\section{RESULTS AND DISCUSSION}

\section{III.1. The structure and morphology of Mn-doped ZnS nanoparticles}

Fig. 1 presents the XRD patterns of $\mathrm{ZnS}: \mathrm{Mn}\left(\mathrm{C}_{M n}=5 \mathrm{~mol} \%\right)$. The patterns show the lines at $28.54,33.02,47.47,56.42$, and $69.45^{\circ}$ which correspond to (111), (002), (220), (311) and (400) diffraction planes. As seen, the (111) peak has the strongest intensity. 

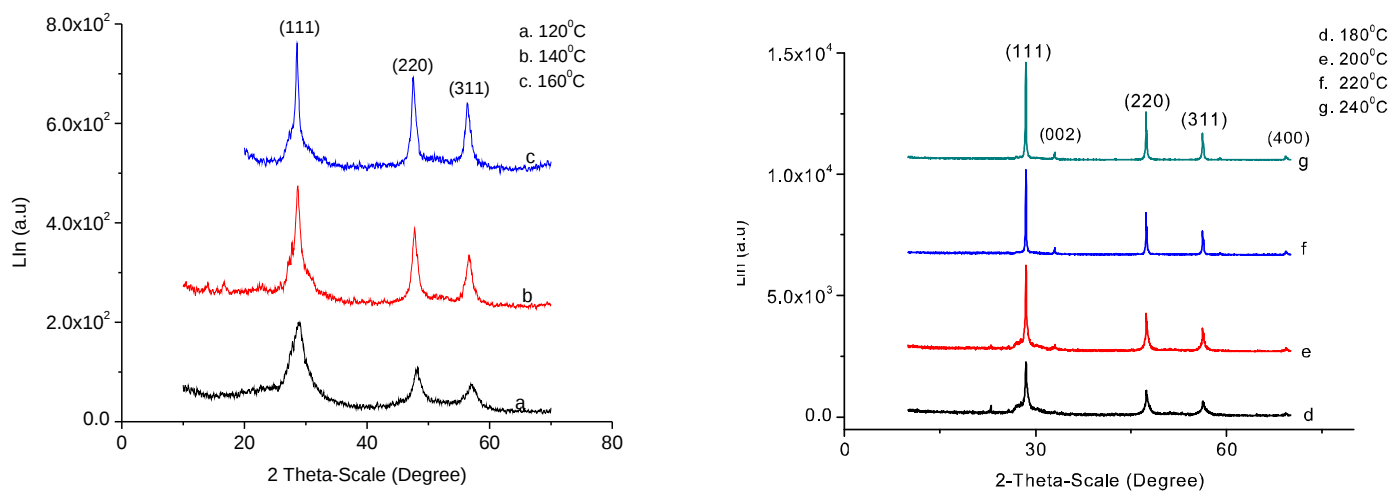

Fig. 1. XRD patterns of $\mathrm{ZnS}: \mathrm{Mn}\left(\mathrm{C}_{M n}=5 \mathrm{~mol} \%\right)$ nanoparticles synthesized for 15 hours at different reaction temperatures

The obtained XRD patterns show that at $120^{\circ} \mathrm{C}$ (Fig. 1(a)) the material has crystallized in both cubic $\left(T_{d}^{2}-F \overline{4} 3 m\right)$ and wurtzite form $\left(C_{6 v}^{4}-P 6_{3} m c\right)$, of which the cubic structure (with the lattice constant $\mathrm{a}=5.355 \AA$ ) was prominent. As the reaction temperature increased from 140 to $160^{\circ} \mathrm{C}$, the full width of diffraction lines decreased and the finger-prints of a cubic phase appeared more clearly (Fig. 1(b)-(c)). The lattice constant of this phase also increased from 5.385 to $5.408 \AA$. As temperature reached $240^{\circ} \mathrm{C}$ the lattice constant expansed further to $5.427 \AA$ (Fig.1(d)-(f)). These values are in good agreement with the JCPDS card no. 05-0566 where $\mathrm{a}=5.406 \AA$. The average crystallite sizes were estimated by the Debye-Scherrer's formular $D=0.9 \lambda /(\beta \cos \theta)$ (where $\beta$ is the full width at half maximum, $\theta$ the diffraction angle and $\lambda$ the wavelength). The obtained size showed the increase from 7.5 to $13.4 \mathrm{~nm}$ according to rising of the reaction temperature from 120 to $160^{\circ} \mathrm{C}$, while further increase of temperature from 180 to $240^{\circ} \mathrm{C}$ seemed to have no effect on the average size which remained unchanged at $16.7 \mathrm{~nm}$. The crystalline structure change as reaction temperature increased may have origin in the kinetics of the complex decomposition reaction: the different decomposition rates at low and high reaction temperature prefer different form of the crystalline structures [7]. The lattice constant change may be due to the different interatomic force in the tetragonal distortion of $\mathrm{ZnS}$ nanostructure [5].

Fig. 2 shows the TEM images of $\mathrm{ZnS}: \mathrm{Mn}\left(\mathrm{C}_{M n}=5 \mathrm{~mol} \%\right)$. As seen, at $120^{\circ} \mathrm{C}$ they formed the microspheres of $1-2 \mu \mathrm{m}$ diameter (Fig. 2(a)) whereas at $180^{\circ} \mathrm{C}$ and $220^{\circ} \mathrm{C}$ they exhibited the form of quasi-spheres with much smaller average size of 20 - $30 \mathrm{~nm}$ (Fig. 2(b), (c)). These values are quite consistent with the results obtained from XRD patterns. This situation is however not obvious as the increase in reaction temperature usually induced larger crystallite size. Indeed we have observed a slight increase in particle size when temperature increased above $180^{\circ} \mathrm{C}$ but the fact that at the temperature higher than $120^{\circ} \mathrm{C}$ the crystallite size gradually reduced posted a question. We believed that the spheres formed at low temperature were larger due to the bridgebinding of organic water because of the $-\mathrm{OH}$ group polarity. The increase in the reaction 
temperature caused the gradual reduction of bridging water molecules, so preventing the aggregation of nanocrystallites to create the larger particles.

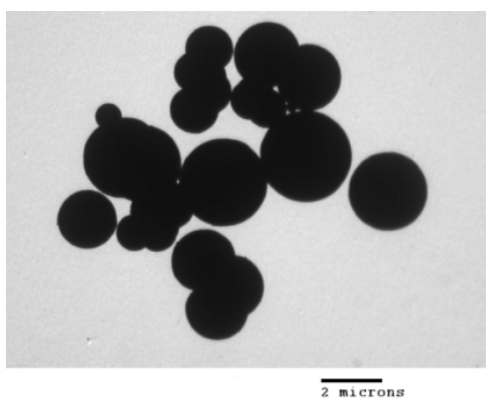

(a)

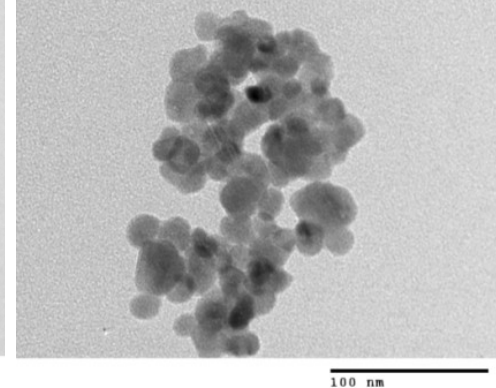

(b)

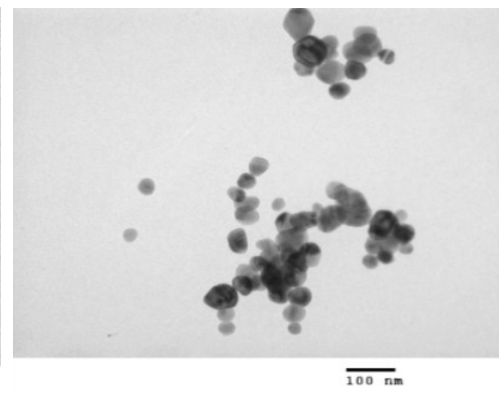

(c)

Fig. 2. TEM images of $\mathrm{ZnS}: \mathrm{Mn}\left(\mathrm{C}_{M n}=5 \mathrm{~mol} \%\right)$ nanoparticles synthesized for 15 hours at some reaction temperatures: 120 (a), 180 (b), and $220^{\circ} \mathrm{C} \mathrm{(c).}$

\section{III.2. The optical properties of $\mathrm{Mn}$-doped $\mathrm{ZnS}$ nanoparticles}

Fig. 3 presents the PL spectra of the sample $\mathrm{ZnS}: \mathrm{Mn}\left(\mathrm{C}_{M n}=5 \mathrm{~mol} \%\right)$. At $120^{\circ} \mathrm{C}$, the PL spectrum exhibits a wide asymmetric band with maximum lying in blue region of $425-500 \mathrm{~nm}$ (Fig. 3(a)). At $140^{\circ} \mathrm{C}$, the blue band reduced its intensity while there appeared a yellow-orange band at about $585 \mathrm{~nm}$ (Fig. 3(b)). At further increase to $160^{\circ} \mathrm{C}$, the intensity of the blue band continuously reduced while the intensity of the yellow - orange band increased rapidly (Fig. 3(c)). This provides a support argument for the interpretation of the blue band as being attributed to the $\mathrm{Zn}$ and $\mathrm{S}$ vacancies at interstitial sites in ZnS structure [9-14]. As the temperature increased further from 180 to $240^{\circ} \mathrm{C}$, the intensity of the yellow-orange continuously increased and achieved the maximum at around $220^{\circ} \mathrm{C}$ (Fig. 3(d)-(g)). This development demonstrates that the yellow-orange band is attributed to the transitions of $\mathrm{Mn}^{2+}$ ions, which is the radiative transition of electrons in the $3 \mathrm{~d}^{5}$ unfilled shell of $\mathrm{Mn}^{2+}\left[{ }^{4} \mathrm{~T}_{1}\left({ }^{4} \mathrm{G}\right)-{ }^{6} \mathrm{~A}_{1}\left({ }^{6} \mathrm{~S}\right)\right][15,16]$. Therefore, the synthesized reaction temperature is an important factor affecting the PL behavior of the $\mathrm{ZnS}: \mathrm{Mn}$ product. At low temperature, the substitution sites of $\mathrm{Mn}^{2+}$ for $\mathrm{Zn}^{2+}$ and the vacancies in the $\mathrm{ZnS}$ microspheres co-exist to allow both blue and yellow-orange emission bands to occur. But at higher reaction temperature the microspheres were broken into nanocrystallites unloading the interstitial vacancy defects and reducing the interparticle absorption. As a result, we observed the decrease of the blue band emission while the intensity of the yellow-orange band gradually increased. As the reaction temperature reached further to $240^{\circ} \mathrm{C}$, a decrease in the emission intensity of the yellow-orange band due to the relaxation effect of $\mathrm{Mn}^{2+}$ substitution sites on the defects at surface was observed $[17,18]$. The dependence of the intensity of yellow-orange band emission on the reaction temperature is showed in Fig. 4. This observation allows to conclude that the reaction temperature above $220^{\circ} \mathrm{C}$ reduces the optical quality of $\mathrm{ZnS}: \mathrm{Mn}$ crystallites due to the probable raising of the number of surface defects. 


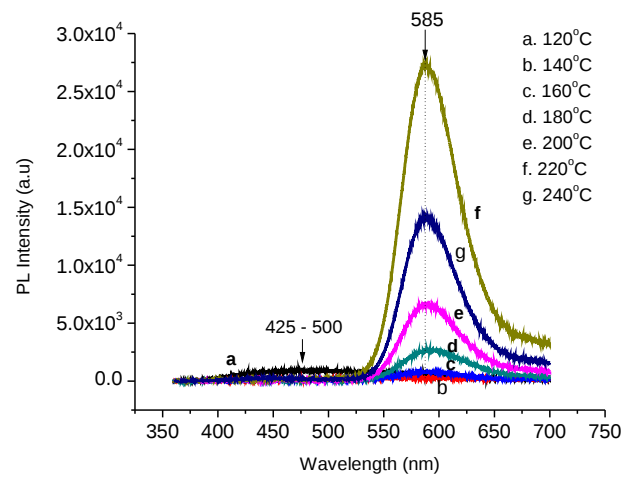

Fig. 3. The PL spectra of $\mathrm{ZnS}: \mathrm{Mn}\left(\mathrm{C}_{M n}=5\right.$ $\mathrm{mol} \%$ ) nanoparticles synthesized for $15 \mathrm{~h}$ at difference reaction temperatures

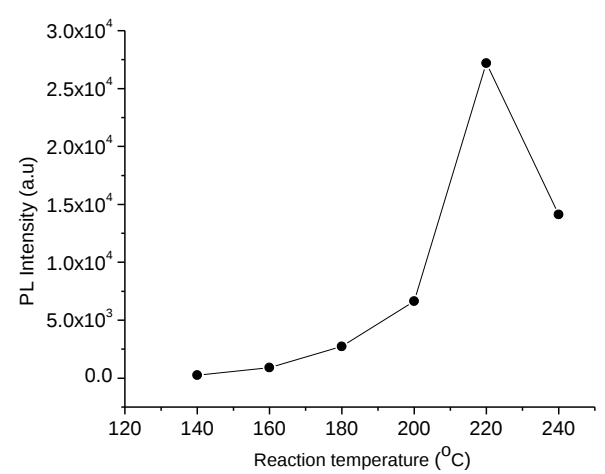

Fig. 4. The dependence of the yelloworange band intensity at $585 \mathrm{~nm}$ on reaction temperature

In order to illustrate the influence of reaction temperature on the optical property of ZnS:Mn nanoparticles, we studied the PLE spectra when monitoring the blue and yellow-orange band. Fig. 5(a) shows the PLE spectrum for a blue band around 425 - 500 $\mathrm{nm}$. There is a main wide band with strong intensity seen at $356 \mathrm{~nm}$. That band can be assigned to the absorption of interstitial $\mathrm{Mn}^{2+}$ sites, or of $\mathrm{Mn}^{2+}$ sites at the surfaces and of impurities presented [17, 18]. Fig. 5(b)-(g) feature the PLE spectra for the yellow-orange band at $585 \mathrm{~nm}$. As seen, at $140^{\circ} \mathrm{C}$ there are a small band with weak intensity at 356 $\mathrm{nm}$ and a wide band with peaks at 398, 468, $493 \mathrm{~nm}$ (Fig. 5(b)). At $160^{\circ} \mathrm{C}$, besides the given bands, there appears a new band at $335 \mathrm{~nm}$ (Fig. $5(\mathrm{c})$ ). At $180^{\circ} \mathrm{C}$, the intensities of all bands increase in comparison with that of $160^{\circ} \mathrm{C}$ but the positions remain unchanged (Fig. 5(d)).

The band at $335 \mathrm{~nm}(3.69 \mathrm{eV})$ can be attributed to the near band edge absorption because the photon energy corresponding to this transition is near the band edge of ZnS $\left(\mathrm{E}_{g}=3.70 \mathrm{eV}\right)[15,16]$. The wide band around $375-550 \mathrm{~nm}$ can be attributed to absorption of $\mathrm{Mn}^{2+}$ ions doping into $\mathrm{ZnS}$ structure, or of $\mathrm{Mn}^{2+}$ interstitial sites and of $\mathrm{Mn}^{2+}$ site at the surfaces.

At $200^{\circ} \mathrm{C}$, the intensity of the near band edge absorption at $335 \mathrm{~nm}$ increases while a wide band around 375-550 nm divides into 4 bands at 390, 430, 467, $494 \mathrm{~nm}$ with lower intensity. Besides, there is a weak band at about $530 \mathrm{~nm}$. These bands are attributed to the absorption transitions of electrons from the ground state ${ }^{6} \mathrm{~A}_{1}\left({ }^{6} \mathrm{~S}\right)$ to the excited states ${ }^{4} \mathrm{E}\left({ }^{4} \mathrm{D}\right) ;{ }^{4} \mathrm{~T}_{2}\left({ }^{4} \mathrm{D}\right) ;{ }^{4} \mathrm{~A}_{1}\left({ }^{4} \mathrm{G}\right)-{ }^{4} \mathrm{E}\left({ }^{4} \mathrm{G}\right) ;{ }^{4} \mathrm{~T}_{2}\left({ }^{4} \mathrm{G}\right),{ }^{4} \mathrm{~T}_{1}\left({ }^{4} \mathrm{G}\right)$ of $\mathrm{Mn}^{2+}$ ions (called $\mathrm{Mn}^{2+}$ absorption bands) [1]. For the temperature increased from 180 to $240^{\circ} \mathrm{C}$, the intensity ratios of $\mathrm{Mn}^{2+}$ absorption bands and the near band edge band increase and reach the maximum at $220^{\circ} \mathrm{C}$ (Fig. 6) but the near band edge absorption position shifts towards to the longer wavelength (around $345 \mathrm{~nm}$ at $220,240^{\circ} \mathrm{C}$ ), the positions of $\mathrm{Mn}^{2+}$ absorption bands remain the same (Fig. 5(d)-(g)). The result presented showed that at the reaction temperature above $200^{\circ} \mathrm{C}$ the absorption caused by the substituted $\mathrm{Mn}^{2+}$ ions completely dominates over the ones of the $\mathrm{Mn}^{2+}$ interstitial sites or at the particles surfaces. 

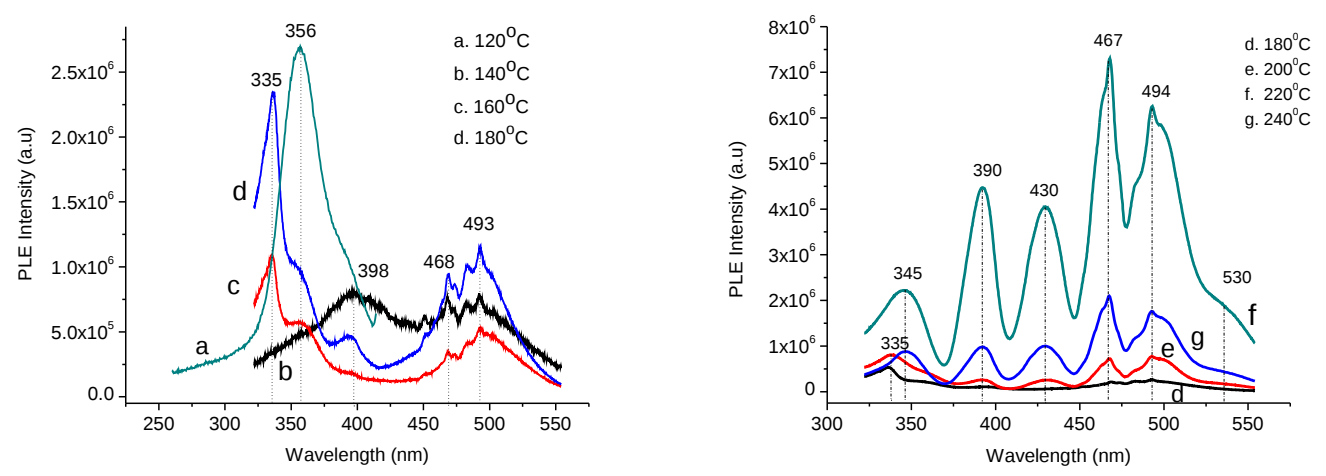

Fig. 5. The PLE spectra of $\mathrm{ZnS}: \mathrm{Mn}\left(\mathrm{C}_{M n}=5 \mathrm{~mol} \%\right)$ nanoparticles synthesized for $15 \mathrm{~h}$ at difference reaction temperatures: (a) monitoring the blue band of $\mathrm{ZnS}: \mathrm{Mn}$ synthesized at $120^{\circ} \mathrm{C}$; and monitoring the yellow-orange of ZnS:Mn synthesized at $140-240^{\circ} \mathrm{C}(\mathrm{b}-\mathrm{g})$

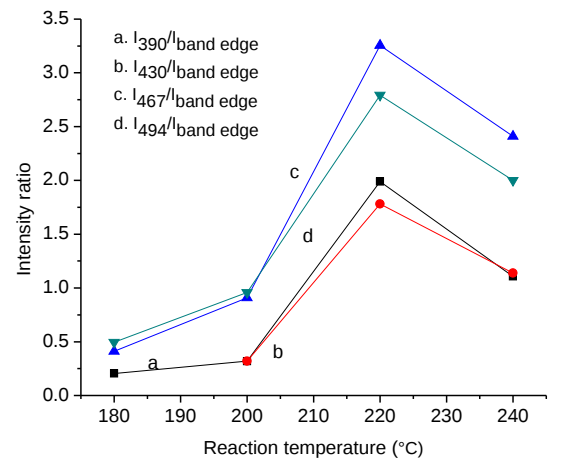

Fig. 6. Intensity ratio of $\mathrm{Mn}^{2+}$ absorption bands and near band edge band according to the reaction temperatures in PLE spectra

To futher illustration the absorption near the band edge and $\mathrm{Mn}^{2+}$ ions absorption in the bulk, we examined the ZnS:Mn absorption spectra. Fig. 7 presents the absorption spectra. The absorption spectra show a wide band at 335 - $347 \mathrm{~nm}$ with strong absorptance. This band is attributed to near the band edge absorption. There are still bands in the range of $375-550 \mathrm{~nm}$ which attribute to the $\mathrm{Mn}^{2+}$ absorption. The appearance of these bands depends on the reaction temperature. At $120^{\circ} \mathrm{C}$, the absorption spectra shows a band around $398 \mathrm{~nm}$ with weak absorptance. This band does not appear in the form of a clear peak and lies near the foot of band edge absorption. At $140^{\circ} \mathrm{C}$, the absorptance of this band increases rapidly, then remains unchanged at 160 and $180^{\circ} \mathrm{C}$ (Fig. 7(b)-(c)).

When increasing the reaction temperature from $180^{\circ} \mathrm{C}$ to $240^{\circ} \mathrm{C}$, the absorption of this band decreases gradually (Fig. $7(\mathrm{~d})-(\mathrm{f})$ ), this proves that the band at $398 \mathrm{~nm}$ can 

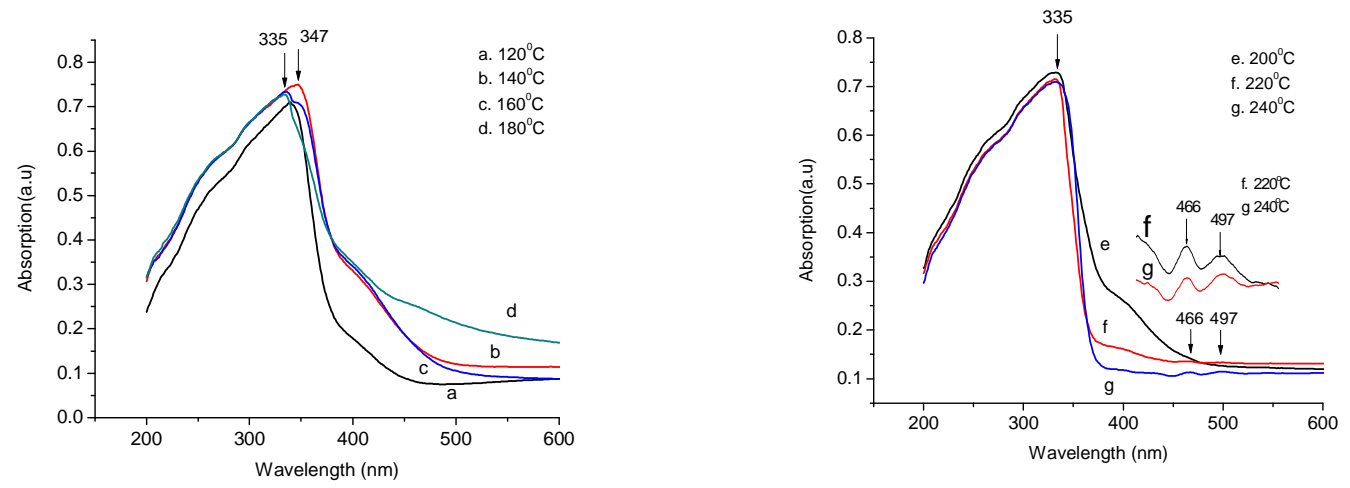

Fig. 7. The absorption spectra of $\mathrm{ZnS}: \mathrm{Mn}\left(\mathrm{C}_{M n}=5 \mathrm{~mol} \%\right)$ nanoparticles synthesized for $15 \mathrm{~h}$ at difference reaction temperatures

be attributed to the absorption of $\mathrm{Mn}^{2+}$ doped into the bulk $\mathrm{ZnS}$ crystal, the interstitial $\mathrm{Mn}^{2+}$ ions and the $\mathrm{Mn}^{2+}$ ions occurred at the particles surfaces, in which the more dominance is the absorption of interstitial $\mathrm{Mn}^{2+}$ ions and $\mathrm{Mn}^{2+}$ ions on the particles surfaces. At 220 and $240^{\circ} \mathrm{C}$, the $\mathrm{Mn}^{2+}$ absorption bands exhibit a form of a clear band at about 466, $497 \mathrm{~nm}$ with weaker absorptance than that of the band near the band edge (Fig. 7(e)-(f)). These bands are attributed to the absorption transitions of electrons from ground state ${ }^{6} \mathrm{~A}_{1}\left({ }^{6} \mathrm{~S}\right)$ to the excited states ${ }^{4} \mathrm{~A}_{1}\left({ }^{4} \mathrm{G}\right)-{ }^{4} \mathrm{E}\left({ }^{4} \mathrm{G}\right) ;{ }^{4} \mathrm{~T}_{2}\left({ }^{4} \mathrm{G}\right)$ of $\mathrm{Mn}^{2+}\left(3 \mathrm{~d}^{5}\right)$ ions, respectively [1].

In turn, we used the radiations of wavelength $325,335-345,356,390,430,467$, 494 and $530 \mathrm{~nm}$ from a xenon lamp (which correspond to the peak positions in the PLE spectra) to excite the $\mathrm{ZnS}: \mathrm{Mn}\left(\mathrm{C}_{M n}=5 \mathrm{~mol} \%\right)$ nanoparticles, we realized that the bands present in $\mathrm{PL}$ spectra depend on the reaction temperature, and at the given reaction temperature the intensity of bands depend on the excited wavelength. At $120^{\circ} \mathrm{C}$, there is only blue band at $450 \mathrm{~nm}$ as excited by $325 \mathrm{~nm}$ radiation (Fig. 8(a)). This fact proves that at this reaction temperature the $\mathrm{Mn}^{2+}$ ions were not substituted into the $\mathrm{ZnS}$ bulk crystallites. At $140^{\circ} \mathrm{C}$ and excited by 325,335 and $356 \mathrm{~nm}$ radiation we observed a blue and a yellow-orange bands at $585 \mathrm{~nm}$, for which the blue band intensity was strongest when excited by $356 \mathrm{~nm}$ radiation. Its intensity gradually reduced if excited by 325 or $335 \mathrm{~nm}$ radiation. Whereas the yellow-orange band intensity achieved the maximum when excited by $325 \mathrm{~nm}$ radiation and gradually reduced when excited by 356 and $335 \mathrm{~nm}$ radiations (Fig. 8(b)-(d)). This demonstrates at that $140^{\circ} \mathrm{C}$ was the reaction temperature at which the $\mathrm{Mn}^{2+}$ ions began to substitute into $\mathrm{ZnS}$ bulk crystallites. At reaction temperatures 160,200 , and $240^{\circ} \mathrm{C}$, the PL spectra of $\mathrm{ZnS}: \mathrm{Mn}$ showed only a yellow-orange band at 585 $\mathrm{nm}$ with the position almost unchanged but with the intensity depended on the wavelength of excitation radiation. At $160^{\circ} \mathrm{C}$, the intensity gradually increased when excited by 325 , 335 , and $356 \mathrm{~nm}$ radiations which possess the photon energy nearly the same as of the band gap (Fig. 9). At $200^{\circ} \mathrm{C}$, the intensity was strongest when excited by $335 \mathrm{~nm}$ radiation, then it reduced when excited by the radiations of $325,494,467,390,430$, and $530 \mathrm{~nm}$ 
(Fig. 10). At $240^{\circ} \mathrm{C}$, the intensity was strongest when excited by $467 \mathrm{~nm}$ radiation, then reduced when excited by 390, 494, 335, 430, 325 and $530 \mathrm{~nm}$ radiations (Fig. 11).

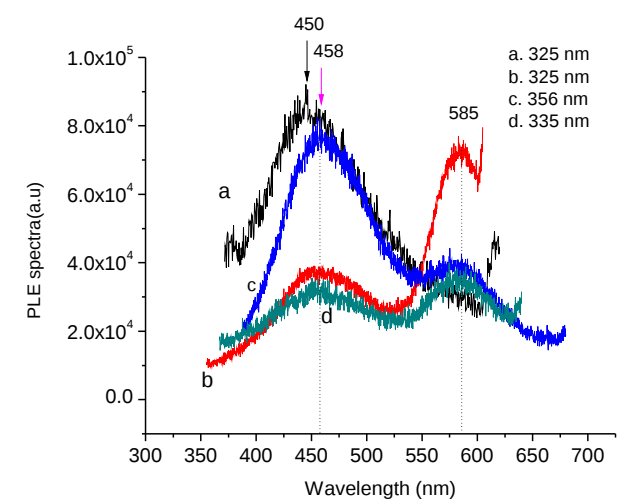

Fig. 8. The PL spectra of $\mathrm{ZnS}: \mathrm{Mn}\left(\mathrm{C}_{M n}=5\right.$ mol\%) nanoparticles synthesized at $120^{\circ} \mathrm{C}($ a) and $140^{\circ} \mathrm{C}(\mathrm{b}, \mathrm{c}, \mathrm{d})$ as excited by difference radiations

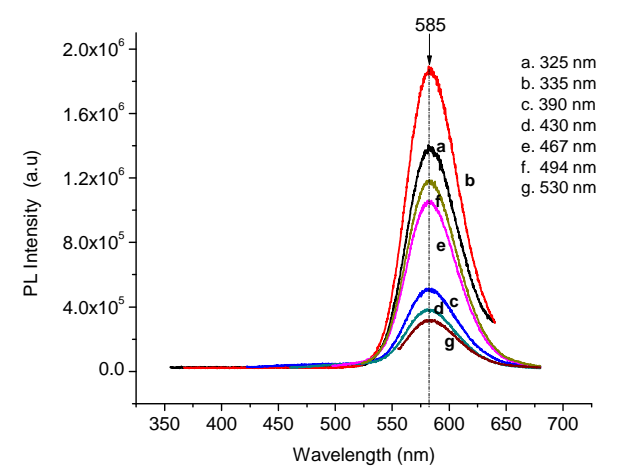

Fig. 10. The PL spectra of $\mathrm{ZnS}: \mathrm{Mn}\left(\mathrm{C}_{M n}=5\right.$ mol\%) nanoparticles synthesized at $200^{\circ} \mathrm{C}$ as excited by difference radiations

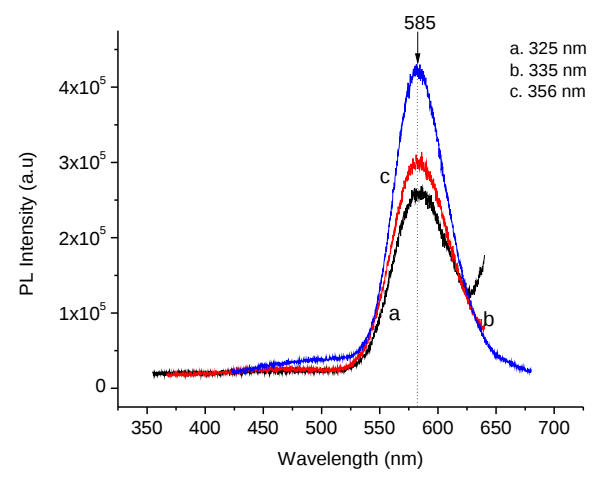

Fig. 9. The PL spectra of ZnS:Mn $\left(\mathrm{C}_{M n}=5 \mathrm{~mol} \%\right)$ nanoparticles synthesized at $160^{\circ} \mathrm{C}$ as excited by difference radiations

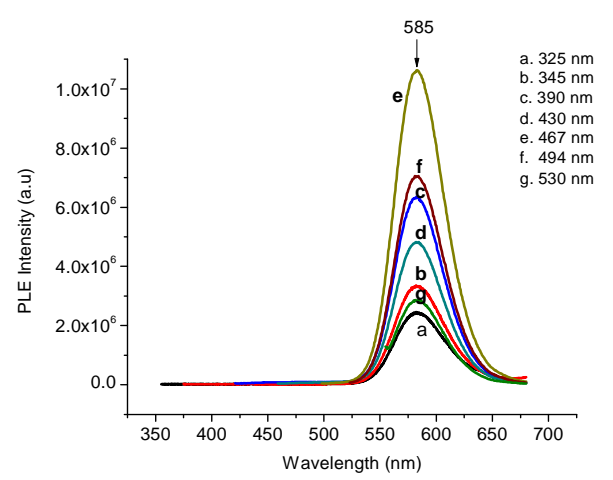

Fig. 11. The PL spectra of ZnS:Mn $\left(\mathrm{C}_{M n}=5 \mathrm{~mol} \%\right)$ nanoparticles synthesized at $240^{\circ} \mathrm{C}$ as excited by difference radiations

The results presented showed that in there may be two excitation mechanisms of $3 \mathrm{~d}^{5}$ electrons of $\mathrm{Mn}^{2+}$ ions: an indirect and direct excitation. In our opinion, the excitation by radiations of $325,335,356 \mathrm{~nm}$ wavelength possesses the photon energy nearly equal to the band gap of $\mathrm{ZnS}$ is indirect excitation, whereas the excitation by radiations of 390, 430, 467, 494, $530 \mathrm{~nm}$ possesses the photon energy smaller than that of the band gap of $\mathrm{ZnS}$ is direct excitation. In addition, indirect excitation is dominant for $\mathrm{ZnS}: \mathrm{Mn}$ nanoparticles synthesized at $180,200^{\circ} \mathrm{C}$; while the ones synthesized at $220,240^{\circ} \mathrm{C}$ prefer the direct excitation. 


\section{CONCLUSION}

The ZnS:Mn $\left(\mathrm{C}_{M n}=5 \mathrm{~mol} \%\right)$ nanoparticles have been synthesized from the solutions of $\mathrm{Zn}\left(\mathrm{CH}_{3} \mathrm{COO}\right)_{2} 0.1 \mathrm{M}, \mathrm{Mn}\left(\mathrm{CH}_{3} \mathrm{COO}\right)_{2} 0.01 \mathrm{M}$ and $\mathrm{Na}_{2} \mathrm{~S}_{2} \mathrm{O}_{3} 0.1 \mathrm{M}$ in a determined volume ratio by the hydrothermal method at varying the reaction temperature from 120 to $240^{\circ} \mathrm{C}$. The XRD patterns, TEM images, absorption, PL, PLE spectra as monitored for the yelloworange band at $585 \mathrm{~nm}$ showed that the increase of reaction temperature from $120^{\circ} \mathrm{C}$ to $220^{\circ} \mathrm{C}$ enhanced the cubic phase quality and the band at $585 \mathrm{~nm}$ should be attributed to the radiative transition of $\mathrm{Mn}^{2+}$ ions while the bands at 390,430,467, 494, $530 \mathrm{~nm}$ were characterized for the absorption of $\mathrm{Mn}^{2+}\left(3 \mathrm{~d}^{5}\right)$ ions in $\mathrm{ZnS}$ crystal. The constant position of the yellow-orange band at $585 \mathrm{~nm}$ in PL spectra as excitation radiations varied and the increase of the emission intensity as reaction temperature varied are the important evidences for the $\mathrm{Mn}^{2+}\left(3 \mathrm{~d}^{5}\right)$ ions substitution for $\mathrm{Zn}^{2+}\left(3 \mathrm{~d}^{10}\right)$ ions in the $\mathrm{ZnS}: \mathrm{Mn}$ structure.

\section{ACKNOWLEDGMENTS}

The authors would like to thank Hanoi University of Science project (code TN.12 04 project) for financial support.

\section{REFERENCES}

[1] Weichen, Ramaswami Sammynaiken, Yining Huang, Jan-Olle Malm, Reine Wallenberg, Jan-Olov Bovin, Valery Zwiller, and Nicholas A. Kotov, Journal of Applied Physics 89(2) (2001) 1120-1129

[2] Daisuke ADachi, Shigeki Hasui, Toshihiko Toyama, and Hiroaki Okamoto, Appl. Phys. Lett. 77(9) (2000) $1301-1303$

[3] Xuan Xue, Jiafu Chen, and Yong Hu, Materials Letters 61 (2007) 115-118

[4] K. R.Murali and S.Kumaresan, Chacogenide Letters 6(1) (2009) 17-22

[5] A. D. Dinsmore, D. S. Hsu, S. B. Qadri, J. O. Cross, T. A. Kenedy, H. F. Gray, and B. R. Ratnan, Journal of Applied Physics 88(95) (2000) 4985-4993

[6] Changlong Jiang, Wangqun Zhang, Guifu Zou, Weicao Yu, and Yitai Qian, Materials Chemistry and Physics 103 (2007) 24-27

[7] Sbiswas and Skar, Nanotechnology 19 (2008) 045710(11 pp).

[8] Masous Salavati-Niasari, Mohammad Reza Loghman-Estarki. Fatemeh Davar, Journal of Alloys and Compounds 475 (2009) 782-788

[9] Li Zhang and Liangbao Yang, Cryst. Res. Technol. 43(10) (2008) 1022-1025

[10] Weichen, Zhanguo Wang, Zhao Jun Lin Yan Xu, and Lanying Lin, J. Mater. Sci. Technol. 13 (1997) 397-404

[11] Xiaosheng Fang and Lide Zhang, J. Mater. Sci. Technol. 22(6) (2006) 721-736

[12] Zhi Gang Chen, Jin Jou, and Dai-Wei Wng, Adv. Funt. Mater. 19 (2009) 484-490

[13] Ying- Chun Zhu, Yoshio Bando, and Dong Feng Xue, Appl. Phys. Lett. 82(11) (2003) 1769-1771

[14] D.Denzler, M.Olschewski and K.Sattler, J. Appl. Phys. 84(5) (1998) 2841-2845

[15] R. N. Bhargava, D. Gallagher, X.Hong and Nurmikko, Phys. Rev. Lett. 72 (1994) 416-419

[16] Bin Xia, I. Wuled Lenggoro, and Kikuo Okuyama, Chem. Mater. 14 (2002) 4960-4974

[17] P. H. Borse, D. Srinivas, R. F. Shinde, S. K. Date, W. Vogel, S. K. Kulkarni, Physical Review B60(12) (1999) 8659- 8664

[18] M. Stefan, S. V. Nistor, D. Ghica, C. D. Mateescu, M. Nikl, and Kucerkova, Physical Review B83 (2011) 04351

Received 20 October 2012. 